International Journal of Instruction e-ISSN: 1308-1470 • www.e-iji.net
July $2017 \bullet$ Vol.10, No.3

p-ISSN: 1694-609X

pp. 93-108

Received: 02/03/2017

Revision: 20/04/2017

Accepted: 25/04/2017

\title{
Development and Evaluation of a Model-Supported Scientific Inquiry Training Program for Elementary Teachers in Indonesia
}

\section{Chandra Ertikanto}

Post-graduate School of Science Education, Faculty of Teacher Training and Education, University of Lampung, Indonesia, chandrafkipunila@gmail.com

\section{Herpratiwi}

Post-graduate School of Educational Technology, Faculty of Teacher Training and Education, University of Lampung, Indonesia, herpratiwi64@yahoo.com

\section{Tina Yunarti}

Post-graduate School of Mathematics Education, Faculty of Teacher Training and Education, University of Lampung, Indonesia,tina_yunarti@yahoo.com

\section{Andrian Saputra}

Department of Chemical Education, Faculty of Teacher Training and Education, University of Lampung, Indonesia, andriansaputra@fkip.unila.ac.id

A teacher training program, named Model-Supported Scientific Inquiry Training Program (MSSITP) has been successfully developed to improve the inquiry skills of Indonesian elementary teachers. The skills enhanced by MSSITP are defining problems, formulating hypotheses, planning and doing investigations, drawing conclusions, and communicating the results. This teacher training program was evaluated by 48 teachers selected by stratified random sampling technique from 48 elementary schools in Bandar Lampung City, Lampung Province, Indonesia. The program was designed to follow Bandura's stages of social learning: attention, retention, production, and motivation. The impact of MSSITP was evaluated in three ways. First, by analyzing the improvements of inquiry skills compared to conventional SITP through pretest and posttest control group design. Second, by using an inquiry questionnaire to describe teachers' perceptions of inquiry learning. Last, by using a response instrument to elicit teachers' opinions of the program. The results indicate a significant difference (sig 0.00) in teachers' skills acquired from the two different training programs. Mean posttest scores, varying from 34.7 to 56.9 for the control group and 58.3 to 98.6 for the experimental group, confirmed the effectiveness of MSSITP.

Keywords: teacher training, research and development, elementary teacher, modelsupported scientific inquiry training program

Citation: Ertikanto, C., Herpratiwi, Yunarti, T. \& Saputra, A. (2017). Development and Evaluation of a Model-Supported Scientific Inquiry Training Program for Elementary Teachers in Indonesia. International Journal of Instruction, 10(3), 93-108. https://doi.org/10.12973/iji.2017.1037a 


\section{INTRODUCTION}

The concept about nature of science is essentially produced by a set of scientific processes such as observing natural phenomena, formulating hypotheses, and testing hypotheses by investigations or experiments (Lederman, 2006; Windschitl et al., 2008), so teaching science should be based on the characteristics of science itself. Students should be trained to find the concepts of science through investigation of phenomena that contextually occur in daily life. One of the best approaches for teaching science is inquiry methods (DeBoer, 1991).

The National Board of Education Standard (2006) in Indonesia lays down that learning science should involve the inquiry processes. This way, students acquire conceptual understanding of science and scientific skills. Several studies confirm that inquiryrelated teaching is effective in (a) enhancing students' science literacy skills and confidence (Gormally et al., 2009); (b) improving student engagement, academic achievement, and learning outcomes (Prince \& Felder, 2006); (c) increasing students' achievement in inquiry laboratories (Luckie, et al., 2004); and (d) deepening conceptual understanding of matter, scientific process skills, and science attitudes for elementary students (Simsek \& Kabapınar, 2010). Therefore, the inquiry method is really important for teaching science at each level of education.

However, and worryingly, the 2015 evaluations of all nations' educational quality by Trend in International Mathematics and Science Study (TIMSS), Progress in International Reading Literacy Study (PIRLS), and also by Program for International Student Assessment (PISA) show that Indonesian primary and secondary school students have only low levels of inquiry skills. Indonesian science students in 2015 ranked as $36^{\text {th }}$ out of 49 countries (Mullis et al., 2016), and only $69^{\text {th }}$ out of 76 countries (OECD, 2016). TIMSS and PISA expose Indonesian students' conceptual difficulties in understanding facts, and putting together appropriate assumptions and solutions, and also in their inability to formulate (let alone solve) scientific problems (Rosen, 2013). Learning science at Indonesian elementary schools has not yet substantially enhanced the inquiry skills of students. Thus, the future choice of inquiry methods for learning science at elementary school is crucial. Students who come to understand the scientific thinking processes at an early school age will find it easier to think at higher educational levels in more complicated cases.

The enhancement of students' inquiry skills is highly affected by teachers' roles as instructors and mentors, as well as motivators (Urhahne et al., 2010; Williams \& Williams, 2011; Allchin et al., 2014; Eshach et al., 2014, Loima \& Vibulphol, 2014; Cheon \& Reeve, 2015; Gillies \& Nichols, 2015). Hattie (2013) states that teachers contribute $30 \%$ to the student achievement; another $50 \%$ is achieved by the students themselves and the remaining $20 \%$ of influence is because of the leadership, the school environment, the peer group and home. Teachers who are competent in managing inquiry classrooms strongly affect their students' academic performance (Blanchard et al., 2010; Bruce et al., 2010). However, some researchers (Crawford, 2000; Lederman \& Niess, 2000) show that elementary teachers in general lack an understanding of inquiry and do not have enough experience effectively to perform science teaching through 
inquiry. The reasons are confusion about the meaning of inquiry, inadequate knowledge in inquiry methodology, and a mind-set that inquiry-based learning is difficult to manage (Welch et al., 1981). In the case of Indonesia, these concerns appear to be exacerbated by the fact that most elementary teachers are not science graduates. Figures from the Centre of Data and Statistics, Ministry of Education and Culture of Indonesia, in 2013 reveal that $28.4 \%$ of the total 3,015,315 teachers have no bachelor degree or diploma, and most of them are elementary school teachers. Additonally, a 2012 national teachers' competency test which also analyzes inquiry skills shows teachers from only seven provinces out of the total of 33 provinces pass the test (Rahman, 2015). Therefore, enhancing inquiry skills is an urgent issue for Indonesian elementary teachers.

Capobianco \& Lehman (2006) recommend an intensive training program to give a better teachers' understanding of inquiry. The involvement in inquiry science experiences helps teachers better conceptualize inquiry and teach it to their students (Kielborn \& Gilmer, 1999). However, Bressoux et al. (2009) note that some -not all-teacher training programs fail to reach their goals. In line with that, Rahman et al. (2015) say that teachers' professional development programs in Indonesia, including various teacher certification programs and other forms of training conducted by local governments or appointed training institutions, have been implemented for over a decade, but are not yet considered to be effective in increasing teacher competence. On the other hand, despite its drawbacks, the training program is believed to be an effective way in introducing new knowledge, and of course it does provide an effective way for dominant stakeholders to control and limit the agenda, and to reduce teachers to a passive role as recipients of specific knowledge (Kennedy, 2005).

In this research, MSSITP is designed to enhance the scientific inquiry skills for Indonesian elementary school teachers. The enhancement of science concepts in this training program is assisted by the trainees' observation of model behaviours as a core business of Bandura's social learning theory. Learning by observation of human behaviour helps to crystallise various concepts and skills that might be difficult to try alone (Bandura et al., 1966). MSSITP is expected to enhance the inquiry skills of elementary school teachers, especially Indonesian teachers.

\section{METHOD}

\section{Sample}

Forty-eight teachers were selected by the stratified random sampling technique from 48 elementary schools in Bandar Lampung City, the capital city of Lampung Province, Indonesia. Bandar Lampung City, we believe, has better educational access than other cities in Lampung Province, Indonesia. Lampung Province overall has low teacher competency, scoring below the national mean on tests. Our sample consisted of 16 elementary teachers at grade 4,16 teachers at grade 5 , and others at grade 6 , all selected by the stratified cluster random sampling technique from 48 elementary schools spread across the suburbs, the middle, and the centre of Bandar Lampung city. Most teachers (83\%) were women and 42 of them were senior teachers with more than 15 years experience and 45 of them worked as full-time teachers. 


\section{Experimental design}

This research followed the seven steps of the Dick \& Carey (1996) model of Research and Development design, i.e. (1) research and information collecting, (2) planning, (3) developing preliminary form of products, (4) preliminary field testing, (5) operational field testing, (6) operational product revision, (7) main field testing. In the first step, we conducted a needs analysis, collecting information from the literature and from a field study. The results of need analysis, literature, and field study were drawn upon to develop training materials, methods, and manuals. The drafts of preliminary work were validated by three experts: one in pedagogical assessment, one in science content, and one in scientific inquiry. Our validated program was trialled on 24 elementary teachers in a suburb of Bandar Lampung City by one group pretest-posttest design. This first evaluation told us how to improve the program. Then, the revised program was ready to be evaluated on a larger scale (48 teachers).

Larger scale evaluation of MSSITP was conducted on 48 elementary teachers from 48 elementary schools in Bandar Lampung by pretest-posttest control group design. The 48 teachers were divided into two groups, experimental and control. All treatments and materials were the same for both groups, except that the experimental group was trained by MSSITP, and the control group received conventional SITP training only (without the modelling). Both programs were implemented in five sessions, each session was seven hours long. Details appear in Table 1 below.

\section{Instrument}

Instruments developed in this research were (1) measurements of inquiry skills (a preand a posttest); (2) an inquiry questionnaire; and (3) a record of teacher responses to the MSSITP. The instruments were validated for reliability, item discrimination, and desirable difficulty level by 22 elementary teachers in Bandar Lampung City. The results showed that only 18 questions were preferably used in this research. Eighteen goodquality questions from the validation were checked again for reliability using the KR-20 method and we found a coefficient of 0.73 which indicated high reliability. Moreover, seven questions in an inquiry questionnaire, given at the beginning and at the end of the program, established the benchmarking for (a) teachers' perceptions of science teaching at elementary school (items no. 1-3); (b) teachers' consciousness of the importance of inquiry-based learning (items no. 4-5); and (c) teachers' understanding of inquiry processes and evaluation (items no. 6-7). In addition, teachers gave their responses to the training materials, activities, lesson plans and scenarios, experiments, and follow-up that they received.

\section{Data analysis}

The validated instruments were examined on main field testing of the experimental and control groups to determine the mean, maximum, minimum, and $\mathrm{N}$-gain value. $\mathrm{N}$-gain value indicates the increasing of inquiry skills for each teacher. Then, the normality test using one sample Kolmogorov-Smirnov $(\alpha=0.05)$ and homogeneity test using Levene test $(\alpha=0.05)$ were performed after $\mathrm{N}$-gain data was obtained. The normally-distributed and homogeneous data were analyzed further using T-test to justify the significance of 
improvements due to the two different training programs, while the non-normal distribution and homogeneous data were processed using the nonparametric MannWhitney test.

\section{FINDINGS}

\section{Result of research}

The instruments of MSSITP were the training manual, the lesson plan structures and schedules, the printed teaching materials, and the exposition of inquiry skills. The general structure of the MSSITP and conventional SITP are presented in Table 1.

Table 1

General structure of Conventional SITP (column 1) and MSSITP (column 2)

\begin{tabular}{|c|c|}
\hline Conventional SITP & MSSITP \\
\hline $\begin{array}{l}\text { First Meeting } \\
\text { Pretest } \\
\text { *Official educational policy and program } \\
\text { orientation } \\
\text { * Researcher prepares syllabus, lesson plan, } \\
\text { assessment test, and inquiry based learning model } \\
\text { * Researcher presents lesson } 1 \text { (float and sink) } \\
\text { * Researcher prepares syllabus, lesson plan and } \\
\text { inquiry based learning model } \\
\text { * Researcher presents theories of lesson } 2 \text { (light } \\
\text { and vision) }\end{array}$ & $\begin{array}{l}\text { First Meeeting } \\
\text { Pretest } \\
\text { *Official educational policy and program orientation } \\
\text { * Researcher prepares syllabus, lesson plan, assessment } \\
\text { test, and inquiry based learning model } \\
\text { * Reseacher beccomes a model for lesson } 1 \text { (float and } \\
\text { sink) } \\
\text { * Model always shows inquiry aspects in all activities } \\
\text { of learning } \\
\text { * Researcher prepares syllabus, lesson plan and inquiry } \\
\text { based learning model } \\
\text { *researcher discusses with the teachers inquiry aspects } \\
\text { arising in lesson } 1\end{array}$ \\
\hline $\begin{array}{l}\text { Second Meeting } \\
\text { *Researcher prepares syllabus, lesson plan, } \\
\text { assessment test, and inquiry based learning model } \\
\text { *Reseacher presents lesson } 3 \text { (solar system) } \\
\text { *During a lesson, researcher acts as a facilitator by } \\
\text { asking about inquiry aspects arising in the lessons } \\
\text { *Researcher discusses with the teachers inquiry } \\
\text { aspects arising in lesson } 1\end{array}$ & $\begin{array}{l}\text { Second Meeting } \\
\text { * Researcher becomes a model of lesson } 2 \text { (light and } \\
\text { vision) } \\
\text { *Model always shows inquiry aspects in all activities } \\
\text { of learning } \\
\text { * Researcher prepares syllabus, lesson plan and inquiry } \\
\text { based learning model } \\
\text { * Researcher discusses with the teachers inquiry } \\
\text { aspects arising in lesson } 2\end{array}$ \\
\hline $\begin{array}{l}\text { Third Meeting } \\
\text { * Researcher discusses with the teachers inquiry } \\
\text { aspects arising in lesson } 2 \\
\text { * Researcher discuss with the teachers inquiry } \\
\text { aspects arising in lesson } 3\end{array}$ & $\begin{array}{l}\text { Third Meeting } \\
\text { *Reseacher becomese a model of lesson } 3 \text { (solar } \\
\text { system) } \\
\text { *Model always shows inquiry aspects in all activities } \\
\text { of learning } \\
\text { *Researcher prepares syllabus, lesson plan and inquiry } \\
\text { based learning model } \\
\text { *Researcher discusses with the teachers inquiry } \\
\text { aspects arising in lesson } 3 \\
\text { Posttest }\end{array}$ \\
\hline $\begin{array}{l}\text { Fourth Meeting } \\
\text { Workshop of lesson planning and peer teaching }\end{array}$ & $\begin{array}{l}\text { Fourth Meeting } \\
\text { Workshop of lesson planning and peer teaching }\end{array}$ \\
\hline $\begin{array}{l}\text { Fifth Meeting } \\
\text { Actual peer teaching }\end{array}$ & $\begin{array}{l}\text { Fifth Meeting } \\
\text { Actual peer teaching }\end{array}$ \\
\hline
\end{tabular}


MSSITP applied Banduras' theory of social learning (1966) which had four processes, as we said: attention, retention, production, and motivation. MSSITP provided training materials such as the national policy on science learning, a model of inquiry learning, lesson plans, a science syllabus, and tools for evaluation. Training exercises were given gradually by the instructor in the form of individual tasks. The lessons on float and sink, light and vision, and the solar system were good examples of the scientific topics that required simple experiments, instead of memorization.

\section{The impact of MSSITP}

Teachers in this research were assessed on their ability to answer the inquiry questions. Inquiry aspects included: defining problems, formulating hypotheses, planning and doing investigations, drawing conclusions, and communicating the results (Pedaste, 2015). The results of the statistical tests of normality and homogeneity, and the difference between the pre- and posttest scores for the experimental and control groups appear in Table 2 .

Table 2

Normality, homogenity, and the difference between two means test of teachers' inquiry skills for both experimental and control group

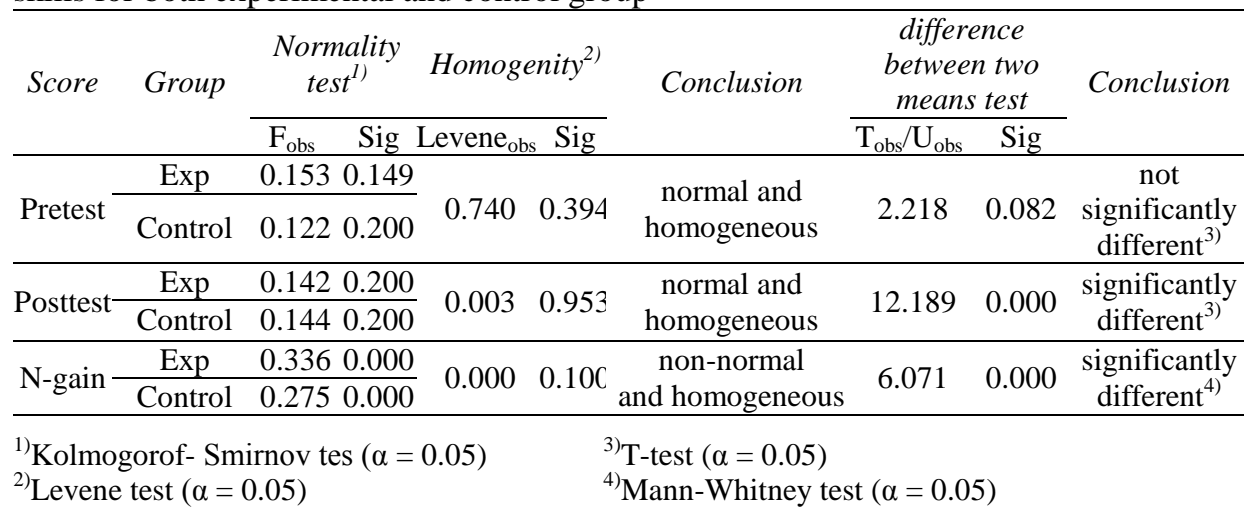

Based on table 2, the pre- and posttest data were normally distributed and homogeneous while N-gain data were homogeneous and not normally distributed lead us to use T-test and Mann-Whitney test, respectively. Moreover, the difference between the two means test for the pretest score in both the experimental and the control group has sig $=0.082$ (that is, sig > 0.05) which means that the inquiry skills of the teachers in both groups were not significantly different before we implemented MSSITP. The posttest score, however, had sig $=0.000$ (that is, sig $<0.05$ ) which indicates that MSSITP produced a significant (and positive) difference in teachers' inquiry skills.

The effect of MSSITP on separate aspects of teachers' inquiry skills is presented in Figure 1 below. Planning and doing investigations had the lowest mean score in pretest (23.6); this indicated that elementary teachers could not plan and conduct a simple experiment to prove or disprove a hypothesis. Meanwhile, the highest mean score in 
pretest (54.2) was for defining problems; this was true for both the control and the experimental group. Then, after the two different programs were implemented, there was an enhancement of all inquiry skills in both groups, but MSSITP produced more improvement than conventional SITP did. For example, the posttest score for planning and doing investigations was 58.3 for the experimental group, while the control group score was 36.1 .

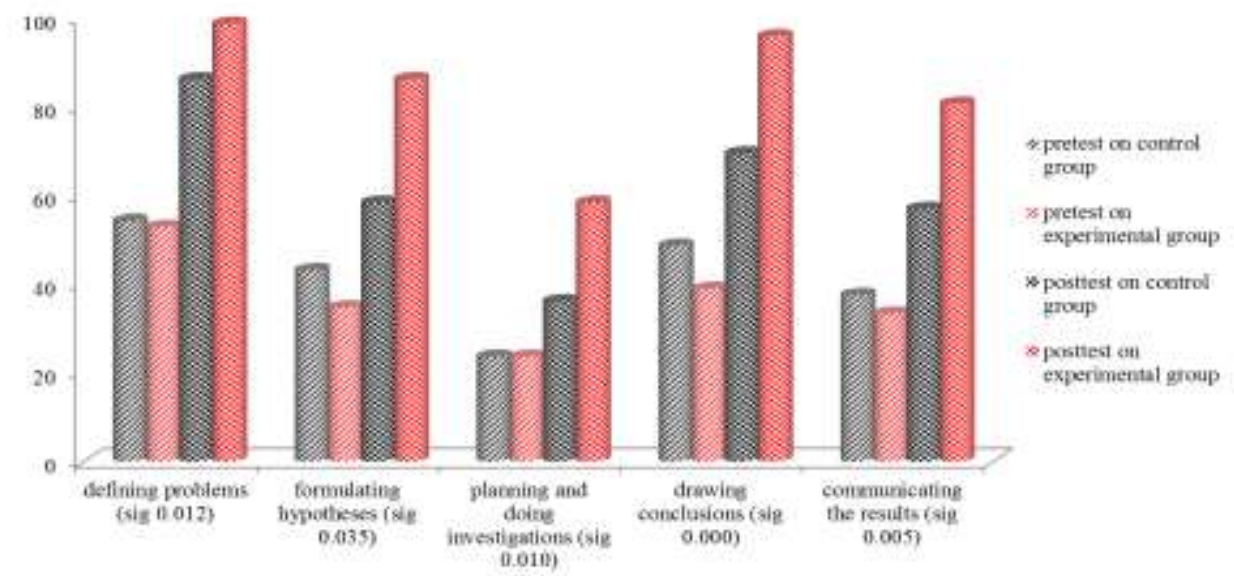

Figure 1

Distribution of the means score of pre- and posttest for control and experimental groups on each inquiry aspect were studied.

This information was also supported by the result of a non-parametric test using MannWhitney test obtained sig $<0.05$ in all inquiry aspects. The $\mathrm{N}$-gain of the experimental group was significantly different from the control group, confirming that MSSITP significantly improved teachers' inquiry skills. Pre- and posttest data were explored more deeply using the inquiry questionnaire (see Table 3 ).

Table 3

The result of teachers' inquiry questionnaire

\begin{tabular}{llcccc}
\hline \multirow{2}{*}{ No } & \multicolumn{1}{c}{ Items } & \multicolumn{2}{c}{ At the beginning } & \multicolumn{2}{c}{ At the end } \\
\cline { 2 - 6 } & & Exp (\%) Control (\%) & Exp (\%) & Control (\%) \\
\hline 1 & Learning science is really important & 58 & 75 & 100 & 100 \\
\hline 2 & Teaching science in elementary school is easy & 54 & 54 & 79 & 75 \\
\hline 3 & $\begin{array}{l}\text { Science topics on elementary school is } \\
\text { sufficiently taught by direct instruction }\end{array}$ & 54 & 37 & 0 & 25 \\
\hline 4 & Inquiry-based learning is a waste of time & 75 & 50 & 0 & 17 \\
\hline 5 & I want to implement inquiry learning & 100 & 100 & 100 & 100 \\
\hline 6 & $\begin{array}{l}\text { I understand the inquiry processes in learning } \\
\text { science }\end{array}$ & 25 & 50 & 66 & 58 \\
\hline 7 & $\begin{array}{l}\text { I understand the evaluation of inquiry-based } \\
\text { learning }\end{array}$ & 25 & 50 & 79 & 83 \\
\hline
\end{tabular}


At the end of the training, teachers gave their response to the MSSITP. Components of MSSITP assessed include training materials and activities, lesson plan, learning activities, experiment, learning scenario, and follow-up as presented in table 4.

Table 4

Teacher responses to the MSSITP

\begin{tabular}{lc}
\hline Components & Positive response \\
\hline Materials & $83 \%$ \\
\hline Training activities & $92 \%$ \\
\hline Lesson plan & $100 \%$ \\
\hline Learning activities & $96 \%$ \\
\hline Experiment & $96 \%$ \\
\hline Learning scenario & $98 \%$ \\
\hline Follow-up & $85 \%$ \\
\hline
\end{tabular}

\section{DISCUSSION}

The Educational Quality Assurance Agency (LPMP) in Lampung Province (2007) reported that elementary school teachers in Lampung Province got a mean score of 46.5 from a standard 80.0 on the teacher competency test for science subjects. Moreover, inquiry skills got a mean value of 33.2 from a maximum of 100 (Ertikanto et al., 2012). These data were supported by our preliminary study that revealed no proper inquiry processes used in lesson plans, only teacher-centered learning, and no hands-on activity. In such conditions, science learning outcomes are always lower than other subjects.

In this research, we developed an inquiry training program, named MSSITP, for elementary teachers, based on Banduras' theory of social learning. Most human learning occurs in a social environment by observing others as a model of abilities both mental and physical (knowledge and skills), attitudes, and beliefs. Learning by observing a modelled behaviour has a set of processes which include: (1) Attention, participants focussed on the models' behaviours that were novel or different in some way, (2) Retention, the behaviours that became the focus of attention were processed cognitively and the results were internalized, (3) Production, information in memory was retrieved in order to reproduce and copy the behaviour. Participants fixed the skills by mental and physical rehearsal. (4) Motivation, was needed for participants consistently to perform attention, retention and production. Motivation was triggered in many ways such as making an interesting lesson, looking for the relationship between learning materials and participants' interest, and giving feedback (reward for learning achievement).

In Table 2, the T-test for pretest shows sig 0.082 ( $\operatorname{sig}>0.05)$, that is, the initial inquiry skills of teachers were not significantly different between the control and experimental groups. This was also supported by the mean score of pretest for each inquiry aspect in Figure 1. The aspect of defining problems has $\mathrm{M}_{\text {con }}=54.2$ for the control group and $\mathrm{M}_{\text {exp }}=52.8$ for the experimental group; planning investigation has $\mathrm{M}_{\mathrm{con}}=43.1$ and $\mathrm{M}_{\mathrm{exp}}$ $=34.7$; formulating hypotheses has $\mathrm{M}_{\mathrm{con}}=23.6$ and $\mathrm{M}_{\mathrm{exp}}=23.6$; drawing conclusions 
has $\mathrm{M}_{\text {con }}=48.6$ and $\mathrm{M}_{\mathrm{exp}}=38.9$; and communicating the result has $\mathrm{M}_{\mathrm{con}}=37.5$ and $\mathrm{M}_{\text {exp }}=33.3$. At pretest, the mean score for each inquiry aspect showed that the control group's initial inquiry skills were similar to, even slightly higher than, the experimental group. After implementation of the two different training programs, T-test for posttest showed sig $=0.00(\mathrm{sig}<0.05)$ indicating that MSSITP and conventional SITP have different effects on teachers' skills. This was confirmed by a mean scores comparison of pre- and posttest and T-test data on every aspect of inquiry skills in Figure 1. Again, MSSITP enhanced inquiry skills more than conventional SITP did. Enhancement of inquiry concepts in this research was caused by sequential and repeated learning on the training structure of MSSITP. We considered that the elementary teachers were analytical learners who preferred information presented in sequential steps, besides a step-by-step approach enables learners easily to acquire information (Pitts, 2009). It was also confirmed that sequence-learning task enhanced the ability to acquire some new procedural skills over practice (Brown et al., 2010). Moreover, models significantly mediated all skills enhancement in this research. According to Bandura \& McDonald (1963), observation of the models' behaviours could considerably shorten the acquisition process. Furthermore, Sáez et al. (2011) also showed significant interactions between student attention and teacher practices. In general, as ratings of attention improved, better performance was associated with better classroom behaviour.

The results of pre- and posttest were also supported by the inquiry questionnaire. At the beginning of the activity, more than half $(>50 \%)$ of the participants stated that (a) teaching science at elementary school was difficult, (b) teaching science was sufficiently done by direct instruction, and (c) science was not important for elementary school students. This statement revealed that elementary teachers had low confidence in their skills in teaching science, probably stemming from their own educational background. As Akerson \& Hanuscin (2007) said, 'most elementary teachers were not science specialists; their lack of experience with science affected their knowledge of science content and resulted in lower confidence about their skills in teaching science'. At the beginning, fewer than half $(<50 \%)$ of participants understood the inquiry process and its foundations in the scientific method. In addition, most of them said that learning science using inquiry method was a waste of time, although all the participants desired to implement the methods in their classrooms.

In contrast to the responses in the beginning, teachers' perceptions changed after the implementation of MSSITP and also after the control, conventional SITP. As shown in Table 3, at the end of each program teachers realized that direct instruction (memory drill) in learning science at elementary school did not lead to concept mastery. Participants became more conscious of the importance of inquiry-based learning, and they gained confidence in teaching science. The teachers' response questionnaire confirmed that MSSITP out-performed conventional SITP (see Table 4). More than $80 \%$ of participants approved of MSSITP's training materials and activities, lesson plan, learning and experimental activities, learning scenario and training follow-up. 


\section{CONCLUSION}

In this paper, we reported on the development of a scientific inquiry training program (MSSITP), and concluded that this program improved teachers' inquiry skills more than did the conventional SITP. The observation of modelled behaviour significantly improved teachers' inquiry skills through shortening the acquisition process. Additionally, the use of sequential and repeated learning in the training structure of MSSITP allowed participants easily to acquire inquiry concepts and skills. Finally, as confirmed by questionnaire, this training program successfully changed participants' perceptions of science teaching and their understanding of inquiry processes.

\section{ACKNOWLEDMENTS}

We owe many thanks to the Board of Education, Local Government of Lampung, and to all teachers, headmasters, and teachers' professional associations (KKG) for their valuable contributions. Special thanks go to to Mrs. Lisa Tania, MSc for constructive discussions in interpreting data.

\section{REFERENCES}

Akerson, V. L., \& Hanuscin, D. L. (2007). Teaching nature of science through inquiry: Results of a 3-year professional development program. Journal of Research in Science Teaching, 44(5), 653-680.

Allchin, D., Andersen, H. M., \& Nielsen, K. (2014). Complementary approaches to teaching nature of science: integrating student inquiry, historical cases, and contemporary cases in classroom practice. Science Education, 98(3), 461-486.

Bandura, A., Grusec, J. E., \& Menlove, F. L. (1966). Observational learning as a function of symbolization and incentive set. Child Development, 37(3), 499-506.

Bandura, A., \& McDonald, F. J. (1963). Influence of social reinforcement and the behavior of models in shaping childern's moral judgments. Journal of Abnormal and Social Psychology, 67(3), 274-281.

Blanchard, M. R., Southerland, S. A., Osborne, J. W., Sampson, V. D., Annetta, L. A., \& Granger, E. M. (2010). Is inquiry possible in light of accountability?: A quantitative comparison of the relative effectiveness of guided inquiry and verification laboratory instruction. Science Education, 94(4), 577-616.

Bressoux, P., Kramarz, F., \& Prost, C. (2009). Teachers' training, class size and students' outcomes: Learning from administrative forecasting mistakes. The Economic Journal, 119(536), 540-561.

Brown, P. J. (2010). Process-oriented guided-inquiry learning in an introductory anatomy and physiology course with a diverse student population. Advances in Physiology Education, 34(3), 150-155. 
Bruce, C. D., Esmonde, I., Ross, J., Dookie, L., \& Beatty, R. (2010). The effects of sustained classroom-embedded teacher professional learning on teacher efficacy and related student achievement. Teaching and Teacher Education, 26(8), 1598-1608.

Capobianco, B., \& Lehman, J. (2006). Integrating technology to foster inquiry in an elementary science methods course: An action research study of one teacher educator's initiatives in a PT3 project. Journal of Computers in Mathematics and Science Teaching, 25(2), 123-146.

Cheon, S. H., \& Reeve, J. (2015). A classroom-based intervention to help teachers decrease students' amotivation. Contemporary Educational Psychology, 40, 99-111.

Crawford, B. A. (2000). Embracing the essence of inquiry: New roles for science teachers. Journal of Research in Science Teaching, 37(9), 916-937.

DeBoer, G. E. (1991). A History of Ideas In Science Education: Implications For Practice. 1234 Amsterdam Avenue, New York, NY 10027: Teachers College Press.

Dick, W., \& Carey, L. (1996). The Systematic Design of Instruction. 4th ed. New York, NY: Harper Collin

Ertikanto, C., Widodo, A., Suhandi, A., \& Tjasyono, H. K. B. (2012). Deskripsi analisis pengetahuan dan kemampuan inkuiri guru sebagai dasar pengembangan pelatihan kemampuan inkuiri dan mengajar sains bagi guru SD [The description of teachers' inquiry knowledge and ability as a basic development of inquiry training for Indonesian elementary teacher]. Seminar Nasional Pendidikan MIPA, FKIP Universitas Lampung, November 2012. Bandar Lampung: Badan Penerbitan FKIP Universitas Lampung.

Eshach, H., Dor-Ziderman, Y., \& Yefroimsky, Y. (2014). Question asking in the science classroom: Teacher attitudes and practices. Journal of Science Education and Technology, 23(1), 67-81.

Gillies, R. M., \& Nichols, K. (2015). How to support primary teachers' implementation of inquiry: Teachers' reflections on teaching cooperative inquiry-based science. Research in Science Education, 45(2), 171-191.

Gormally, C., Brickman, P., Hallar, B., \& Armstrong, N. (2009). Effects of inquirybased learning on students' science literacy skills and confidence. International Journal for the Scholarship of Teaching and Learning, 3(2), 1-22.

Hattie, J. (2003). Teachers make a difference: What is the research evidence?. Australian Council for Educational Research (ACER) Conference, Melbourne, 19 - 21st October 2003. Camberwell, Vic.: Australian Council for Educational Research. Retrieved 27 February, 2017 from http://research.acer.edu.au/research_conference_2003/4/

Kennedy, A. (2005). Models of continuing professional development: a framework for analysis. Journal of In-Service Education, 31(2), 235-250.

Kielborn, T. L., \& Gilmer, P. J. (1999). Meaningful Science: Teachers Doing Inquiry+ Teaching Science. Tallahassee, FL: ERIC. 
Lederman, N. G. (2006). Syntax of nature of science within inquiry and science instruction. In Scientific inquiry and nature of science (pp. 301-317). The Netherlands: Springer Netherlands.

Lederman, N. G., Abd-El-Khalick, F., Bell, R. L., \& Schwartz, R. S. (2002). Views of nature of science questionnaire: Toward valid and meaningful assessment of learners' conceptions of nature of science. Journal of Research in Science Teaching, 39(6), 497521.

Lederman, N. G., \& Niess, M. L. (2000). Problem solving and solving problems: inquiry about inquiry. School Science and Mathematics, 100(3), 113-116.

Loima, J., \& Vibulphol, J. (2014). Internal interest or external performing? A qualitative study on motivation and learning of 9 th graders in Thailand basic education. Journal of Education and Learning, 3(3), 194-203.

Luckie, D. B., Maleszewski, J. J., Loznak, S. D., \& Krha, M. (2004). Infusion of collaborative inquiry throughout a biology curriculum increases student learning: a fouryear study of "Teams and Streams". Advances in Physiology Education, 28(4), 199-209.

Mullis, I. V. S., Martin, M. O., Foy, P., \& Hooper, M. (2016). TIMSS 2015 International Results in Mathematics. Boston College, TIMSS \& PIRLS International Study Center. $\quad$ Retrieved $26 \quad$ February, 2017 from http://timssandpirls.bc.edu/timss2015/international-results/

National Board of Education Standard. (2006). Retrieved 05 April, 2017 from http://bsnp-indonesia.org/wp-content/uploads/kompetensi/Panduan_Umum_KTSP.pdf

OECD. (2016). PISA 2015 results (volume I): Excellence and equity in education. Paris: OECD Publishing.

Pedaste, M., Mäeots, M., Siiman, L. A., De Jong, T., Van Riesen, S. A., Kamp, E. T., ... \& Tsourlidaki, E. (2015). Phases of inquiry-based learning: Definitions and the inquiry cycle. Educational Research Review, 14, 47-61.

Pitts, J. (2009). Identifying and using a teacher-friendly learning-styles instrument. The Clearing House: A Journal of Educational Strategies, Issues and Ideas, 82(5), 225-232.

Prince, M. J., \& Felder, R. M. (2006). Inductive teaching and learning methods: Definitions, comparisons, and research bases. Journal of Engineering Education, 95(2), 123-138.

Rahman, B. (2015). Mempersiapkan guru profesional: suatu pendekatan komprehensif (Preparing a professional teachers: a comprehensive approach). Bandar Lampung: Badan Penerbitan FKIP Universitas Lampung.

Rahman, B., Abdurrahman, A., Kadaryanto, B., \& Rusminto, N. E. (2015). Teacherbased scaffolding as a teacher professional development program in Indonesia. Australian Journal of Teacher Education, 40(11), 67-78. 
Rosen, Y., \& Tager, M. (2013). Evidence-centered concept map as a thinking tool in critical thinking computer based assessment. The 39th Annual International Association for Educational Assessment Conference (IAEA), the National Institute for Testing and Evaluation (NITE), 20-25 October 2013. Tel Aviv, Israel: International Association for Educational Assessment.

Sáez, L., Folsom, J. S., Al Otaiba, S., \& Schatschneider, C. (2012). Relations among student attention behaviors, teacher practices, and beginning word reading skill. Journal of Learning Disabilities, 45(5), 418-432.

Simsek, P. \& Kabapmar (2010). The effects of inquiry-based learning on elementary students'conceptual understanding of matter, scientific process skills and science attitudes. World Conference on Educational Sciences, Bahcesehir University, 4-8 February 2010. Istanbul, Turkey: Elsevier.

Urhahne, D., Schanze, S., Bell, T., Mansfield, A., \& Holmes, J. (2010). Role of the teacher in computer-supported collaborative inquiry learning. International Journal of Science Education, 32(2), 221-243.

Welch, W. W., Klopfer, L. E., Aikenhead, G. S., \& Robinson, J. T. (1981). The role of inquiry in science education: Analysis and recommendations. Science Education, 65(1), 33-50.

Williams, K. C., \& Williams, C. C. (2011). Five key ingredients for improving student motivation. Research in Higher Education Journal, 12(1), 1-23.

Windschitl, M., Thompson, J., \& Braaten, M. (2008). Beyond the scientific method: Model-based inquiry as a new paradigm of preference for school science investigations. Science Education, 92(5), 941-967. 


\section{Turkish Abstract \\ Endonezya'daki İlköğretim Öğretmenlerine Yönelik Model Destekli Bir Bilimsel Araştırma Eğitim Programının Geliştirilmesi ve Değerlendirilmesi}

Endonezyalı ilköğretim öğretmenlerinin araștırma becerilerini geliștirmek için başarılı bir şekilde Model Destekli Bilimsel Araştırma Eğitim Programı (MSSITP) adlı bir öğretmen eğitimi programı geliștirilmiștir. MSSITP tarafından geliștirilen bu beceriler, sorunları tanımlamak, hipotezleri formüle etmek, araştırma planlamak ve yapmak, sonuç çıkarmak ve sonuçları iletmektir. Bu öğretmen eğitimi, Endonezya'nın Lampung İlçesi, Bandar Lampung Şehrindeki 48 ilköğretim okulundan tabakalı rasgele örnekleme tekniği ile seçilen 48 öğretmen tarafindan değerlendirilmiştir. Program, dikkat, saklama, üretim ve motivasyon olan Bandura'nın sosyal öğrenme aşamalarını takip etmek üzere tasarlanmıştır.. MSSITP'nin etkisi üç yolla değerlendirilmiştir.

Anahtar Kelimeler: öğretmen eğitimi, araştırma ve geliştirme, ilkokul öğretmeni, model destekli bilimsel eğitim programı

\section{French Abstract \\ Développement et Évaluation d'un Programme de formation d'Enquête Scientifique Supporté de modèle pour Professeurs des écoles en Indonésie}

Un programme de formation de professeur, nommé le Programme de formation d'Enquête Scientifique Soutenu de modèle (MSSITP) a été avec succès développé pour améliorer les compétences d'enquête de professeurs des écoles indonésiens. Les compétences améliorées par MSSITP définissent des problèmes, formulant des hypothèses, planifiant et faisant des enquêtes, tirant des conclusions et communiquant les résultats. Ce programme de formation de professeur a été évalué par 48 professeurs choisis par la technique d'échantillonnage aléatoire stratifiée de 48 écoles primaires dans la Ville de Bandar Lampung, la Province de Lampung, l'Indonésie. Le programme a été conçu pour suivre les étapes d'apprentissage social de Bandura: attention, rétention, production et motivation. L'impact de MSSITP a été évalué de trois façons.

Mots Clés: formation de professeur, recherche et développement, professeur des écoles, modèle Programme de formation d'enquête scientifique soutenu

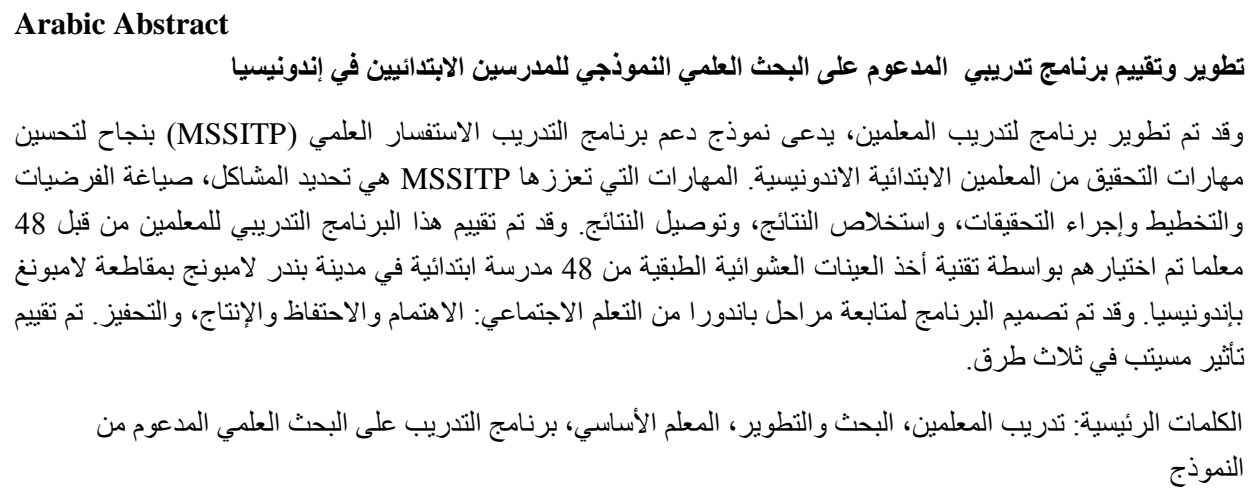




\section{German Abstract \\ Entwicklung und Evaluation eines modellgestützten wissenschaftlichen Instruktionsprogramms für Grundlehrer in Indonesien}

Ein Lehrer-Trainingsprogramm namens Model-Supported Scientific Inquiry Training Program (MSSITP) wurde erfolgreich entwickelt, um die Anfrage Fähigkeiten der indonesischen Grundlehrer zu verbessern. Die von MSSITP verbesserten Fähigkeiten definieren Probleme, formulieren Hypothesen, planen und erarbeiten Untersuchungen, ziehen Schlussfolgerungen und vermitteln die Ergebnisse. Dieses Lehrerausbildungsprogramm wurde von 48 Lehrern ausgewählt, die von einer geschichteten Stichprobenverfahren von 48 Grundschulen in der Bandar Lampung Stadt, Provinz Lampung, Indonesien, ausgewählt wurden. Das Programm wurde entwickelt, um Banduras Phasen des sozialen Lernens zu folgen: Aufmerksamkeit, Aufbewahrung, Produktion und Motivation. Die Auswirkungen von MSSITP wurden auf drei Arten bewertet.

Schlüsselwörter: lehrerausbildung, forschung und entwicklung, grundschullehrer, modellgestütztes wissenschaftliches untersuchungsprogramm

\section{Malaysian Abstract \\ Pembangunan dan Penilaian Model Inkuiri Saintifik Program Latihan Guru-guru Sekolah Rendah di Indonesia}

Satu program latihan guru, yang dinamakan Model-Inkuiri Saintifik Program Latihan (MSSITP) telah berjaya dibangunkan untuk meningkatkan kemahiran inkuiri guru rendah Indonesia. Kemahiran dipertingkatkan dengan MSSITP mendefinisikan masalah, merumuskan hipotesis, merancang dan melakukan penyiasatan, membuat kesimpulan, dan memaklumkan hasil. Program latihan guru telah dinilai oleh 48 orang guru yang dipilih secara persampelan rawak berstrata dari 48 buah sekolah rendah di Bandar Lampung City, Provinsi Lampung, Indonesia. Program ini direka untuk mengikuti peringkat Bandura pembelajaran sosial: perhatian, penyimpanan, pengeluaran, dan motivasi. Kesan MSSITP dinilai dalam tiga cara.

Kata Kunci: latihan guru, penyelidikan dan pembangunan, guru rendah, model- disokong program latihan penyelidikan saintifik

\section{Russian Abstract \\ Разработка Разработка и Оценка Программы Поддержки Научных Исследований в Области Моделирования для Учителей начальных Классов в Индонезии}

Была успешно разработана программа подготовки преподавателей под названием Программы Поддержки Научных Исследований в Области Моделирования (MSSITP), которая направлена на совершенствование навыков изучения индонезийских учителей начальных классов. Навыки, усиленные MSSITP, определяют проблемы, формулируют гипотезы, планируют и проводят исследования, делают выводы и сообщают результаты. Эта программа обучения учителей была оценена 48 учителями, отобранными по методу случайного выбора из 48 начальных школ города Бандар Лампунг, провинция Лампунг, Индонезия. Программа была разработана, для того, чтобы следовать этапам Бандуры социального обучения: внимание, удержание, производство и мотивация. Воздействие 
MSSITP было оценено тремя способами.

Ключевые Слова: подготовка преподавателей, научные исследования и разработки, учитель начальной школы, программы поддержки научных исследований в области моделирования 